\title{
The Problem of Authenticity of Bishop Nicholai Velimirovich's Eulogy of Dimitrije Ljotić on April 24, 1945*
}

\author{
Rastko Lompar \\ Institute for Balkan Studies, Serbian Academy of Science and Arts, Belgrade \\ rastko.lompar@bi.sanu.ac.rs \\ ORCiD https://orcid.org/0000-0003-4345-4857
}

Abstract: This paper analyzes Bishop Nicholai Velimirovich's eulogy of Dimitrije Ljotić on April 24, 1945. Furthermore, this paper follows the debate surrounding the speech's authenticity. It aims not only to provide an outline of existing arguments but also to broaden the discussion using the author's own research and interpretations.

Key words: Nicholai Velimirovich, Dimitrije Ljotić, authenticity, eulogy.

\section{Проблем аутентичности говора Епископа Николаја Велимировића над одром Димитрија Љотића 24. априла 1945. године}

Растко Ломпар

Балканолошки институт САНУ, Београд

Апстракт: У раду се анализира говор који је епископ Николај Велимировић изговорио над одром Димитрија Љотића 24. априла 1945, као и дебата око његове аутентичности и полемика која је по том питању вођена. Поред прегледа постојећих аргумената настојаћемо да допринесемо дебати сопственим истраживањима и интерпретацијама.

Кључне речи: Епископ Николај Велимировић, Димитрије Љотић, аутентичност, говор над одром.

\footnotetext{
" Истраживање спроведено уз подршку Фонда за науку Републике Србије, ПРОМИС, евиденциони број пројекта 6о62708, акроним SerbRightWing.
} 


\section{Увод}

Говор Николаја Велимировића над одром Димитрија Љотића први пут је широј јавности постао познат када је Љотићев лични секретар Бошко Костић објавио књигу сећања За исйорију наших gана у Лилу 1949. године (Костић 1949). Књига је изазвала велико интересовање, доживела је неколико поновних издања $(1991,1995,2011)$ и до данас представља неизоставан извор за све проучаваоце Димитрија Љотића и Југословенског народног покрета 3бор. Чланови Збора су се са садржајем говора могли упознати и на страницама ванредног броја Наще борбе од 25. априла 1945. године, али тек захваљујући књизи Бошка Костића се широка публика сусрела са речима које је наводно изговорио Николај Велимировић. ${ }^{1}$ Упркос чињеници да је зборашко виђење догађаја у Југославији током Другог светског рата било, а и даље јесте, предмет дубоких полемика и оспоравања, овај говор прихватан је као аутентичан све до осамдесетих година 2о. века. Ни жестоки противници Димитрија Љотића, попут Вељка Рашевића, нису све оспоравали његову аутентичност (Рашевић 1953, 7).

Први је веродостојност овог говора довео у питање крајем осамдесетих година јеромонах Атанасије Јевтић, каснији епископ захумско-херцеговачки. Он је 1986. године објавио неколико текстова у којима је оспоравао аутентичност овог говора. У полемику која је уследила из његовог писања укључио се и Момчило Ђујић који је објавио текст И ја сам свеgок бранећи његову аутентичност. ${ }^{2}$ Након овога расправа је у извесној мери утихнула

\footnotetext{
${ }^{1}$ Не желећи да прејудицирамо његову аутентичност, а да не бисмо оптерећивали текст константним навођењем епитета „наводни“, ми ћемо писати у даљем тексту као да га је доиста изговорио Николај Велимировић.

2 Види Јевтић 1986а; Јевтић 1986б; Јевтић 1986в, 51-63; Ђујић 1987. Писма Атанасију Јевтићу упутили су Бошко Костић и Светомир Пауновић
} 
да би поново се разбуктала у догађајима око канонизације Николаја Велимировића 2003. године. Тада је јереј Велибор Џомић почео са објављивањем критичких текстова о љотићевцима, а поготово о њиховом понашању према СПЦ током окупације (Џомић 2003, 426-439; Пауновић 2003; Карапанџић 2003; Џомић 2004). На његово писање у Поіледима и Книжевним новинама реаговали су познати зборашки публицисти Светомир Пауновић и Боривоје Карапанџић. У полемику вођену на страницама Искре и Книжевних новина укључио се и Душан Поповић, бивши војник Динарске дивизије, тврдећи да је и он сведок говора. У основи, расправа из 2003-2004. године, иако у великој мери вођена ad hominem, презентовала је главне аргументе обе стране. ${ }^{3}$

Сматрамо да је дебата око аутентичности овог говора нераскидиво везана за процес канонизације Николаја Велимировића. Због тога је његова аутентичност оспорена тек педесетак година након што је изговорен, а не непосредно након његовог објављивања док су ране из грађанског рата биле неупоредиво свежије. Први „талас“ оспоравања догодио се непосредно пре „неформалне“ канонизације Николаја Велимировића 1987. године, док је други подстакнут његовом званичном канонизацијом 2003. године. Обе стране у дебати су то, на различит начин, и тврдиле. Боривоје Карапанџић је истицао да Џомићеви текстови „имају за циљ да одвоје сарадњу и пријатељство Димитрија Љотића од блажене успомене тадашњег Епископа а садашњег Светитеља Николаја“ (Карапанџић 20о3). Велибор Џомић је образлагао због чега је питање аутентичности овог говора веома важно речима: „сви србски непријатељи... на том фамозном и бестидном љотићевском фалсификату бесе-

и она су објављена у Пауновић 2006, 13-19. Момчило Ђујић се на питање аутентичности осврнуо и у интервјуу Милу Глигоријевићу (уп. Глигоријевић 2009, 208).

${ }^{3}$ Оба аутора су своје текстове објавили и у сопственим књигама; види Карапанџић 2008; Џомић 2009. 
де Светога Николаја над Љотићевим одром деценијама и данас посебно клевећу и оптужују Србску Цркву, Светог Владику Николаја и Србски народ“ (Џомић 2009, 244). Обе стране су тиме јасно указале на разлоге својих настојања. Следбеници Димитрија Љотића виђење свог „учитеља“ баштине и доказују великим делом на ласкавим речима упућеним од стране Николаја Велимировића, као човека са неупоредиво већим угледом и утицајем. Са друге стране присталице канонизације Николаја Велимировића настоје да, оповргнувши аутентичност овог говора, „одвоје“Николаја Велимировића од личности чији је политички ангажман, поготово током Другог светског рата, у науци и широј јавности, оптерећен сарадњом са окупатором, хапшењима и убиствима противника.

Не улазећи на овом месту у неупоредиво познатију и комплекснију дебату око оправданости канонизације епископа Николаја 2003. године, желимо да укажемо на то колику је улогу говор над одром Димитрија Љотића имао у њој. Готово сви критичари канонизације Николаја Велимировића наводили су овај говор (Byford 2004; Ђорђевић 20о8). Уз говор је навођено и неколико стихова о Димитрију Љотићу из песме Николаја Велимировића о националној слози, насталој 1945. године. Ови стихови су понекада називани и „тропаром“ и „химном“ Димитрију Љотићу (Đorđević 2010, 41). У намери да се докаже и прикаже чвршћом веза између Николаја Велимировића и Димитрија Љотића долазило је и до измена његовог говора. Јован Бајфорд је, пишући о Николају Велимировићу, његову реченицу да је Љотић „био идеолог хришћанског национализма“ пренео као „идеолог клерикалног национализма“ (Byford 2004, 8). Замена речи „хришћанског“ са „клерикалног“ имала је функцију оснаживања везе између Љотића и Велимировића и дубљу компромитацију Велимировића. 


\section{Верзије говора}

До сада је у науци и публицистици владало мишљење да је једина верзија говора Николаја Велимировића на одру Димитрија Љотића публикована у оквиру књиге Бошка Костића За истиорију наших gана. Ту чињеницу су наводили и оспораватељи веродостојности желећи да га представе као измишљотину Бошка Костића. Међутим, на основу наших сазнања, постоје још четири различите верзије овог говора, од којих су две објављене у монографијама, док се друге две чувају у архивима. Бошко Костић је у писму упућеном Атанасију Јевтићу писао како је он преузео текст говора из

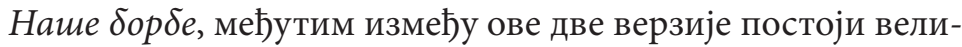
ки број разлика (Пауновић 2006, 14).

Према нашем мишљењу, најверодостојнија верзија овог говора похрањена је у Војном архиву, у кутији у којој је грађа везана за Српски добровољачки корпус. ${ }^{4}$ У питању је ћириличним писмом куцан документ на четири стране насловљен као Говор ейискойа Николаја наg оgром министира Димитирија Љойића. Сам документ први је открио Младен Стефановић и на основу њега је и писао о дешавањима 24. априла 1945. године (Стефановић 1984, 327328). Иако га је користио, Стефановић није уочио да је у питању текст који се у извесној мери разликује од оног који је објавио Костић, нити је настојао да га анализира. Верзија из Војног архива је готово истоветна тексту говора објављеном у Нашој борби од 25. априла 1945. године, те се може сматрати да је она послужила као узор приликом израде овог броја. ${ }^{5}$

У Историјском архиву Београда у оквиру Збирке о раду Љотићеве организације 3бор чува се документ насловљен као Посмриини іовор еиискойа Николаја Димитирију

\footnotetext{
${ }^{4}$ Војни Архив (ВА), Недићева архива (НА), Ф3, Д33, Говор епископа Николаја над одром министра Димитрија Љотића.

${ }^{5}$ Аноним, „Певајте у славу Димитрија Љотића“, Наша Борба, 25. о4. 1945.
} 
Љотиићу. ${ }^{6}$ Документ је куцан латиничним писмом на три стране. С обзиром на то да је ова збирка настала као откуп од Младена Стефановића и да је на самом документу откуцана сигнатура Архива Војноисторијског института ми сматрамо овај документ неаутентичним. Према нашем мишљењу, у питању је препис који је Младен Стефановић саставио на основу документа из Војног Архива (тадашњег Архива Војноисторијског института), те се и мале разлике између ова два документа могу атрибуирати грешкама приликом преписа. С обзиром на то одлучили смо да овај документ не користимо приликом састављања интегралног текста овог говора.

Трећа верзија овог говора објављена је у књизи Ђура Ј. Врге Осйала су свеgочена (Врга 2007, 87-92). Ђуро Врга био је током рата релативно непознат добровољац и неко време секретар Јакова Јаше Љотића, рођеног брата Димитрија Љотића и старешине Збора након његове погибије. Ђуро Врга је касније емигрирао у Сједињене Америчке Државе где је и умро. Ова књига објављено је постхумно, од докумената из његове заоставштине. Међу бројним материјалима који се у њој налазе објављена је и верзија говора Николаја Велимировића насловљена Слово еиискойа Жичког Николаја. Приређивач Момир Вуковић такође није уочио и истакао разлике у тексту између овог и Костићевог текста.

Четврта верзија говора објављена је у књизи Светомира Пауновића Светии влаgика Николај срйски и юеі̄ови

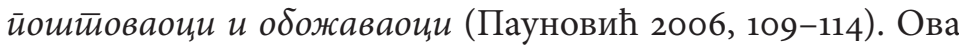
књига представља компилацију свих зборашких аргумената у корист аутентичности говора и обилује нападима и ув-

\footnotetext{
${ }^{6}$ Историјски архив Београда (ИаБ), Збирка о раду Љотићеве организације Збор (1929), кутија 2.

7 Према нашем мишљењу, у збирци нема оригиналних документа, већ искључиво копија и преписа. Међутим, због тога што се ту налазе документа из српских, словеначких, хрватских и немачких архива она представља путоказ свим истраживачима заинтересованим за 3бор.
} 
редама на његове оспораватеље. Иако је аутор наводио да он преузео текст говора од Бошка Костића, текст говора који је он објавио није истоветан Костићевом. Посебно загонетна чињеница јесте да се у овој верзији налази једна реченица коју ниједна друга верзија не садржи, што повлачи питање Пауновићевог извора.

Сама чињеница да је овај говор сачуван и као архивски документ не обесмишљава расправу о његовој аутентичности. С обзиром на то да, према нашим сазнањима, никада није указано на различите верзије говора, нити су оне анализиране, сматрамо да је важно да се прикаже интегрални текст овог говора. Као основну верзију узели смо документ Говор ейискойа Николаја наg оgром

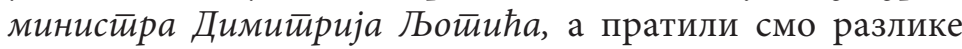
у односу на текст објављен у Нашој борби (у коментарима НБ) и у књигама Бошка Костића (у коментарима БК), Светомира Пауновића (у коментарима СП) и Ђура Врге (у коментарима ЂВ).

\section{Текст говора}

Ваша Светости, тужни зборе! ${ }^{8}$

9 Да је отсечена само једна грана, стабло не би много осетило, али стабло је отсечено до корена и нама је нанесен велики бол. Ај Боже! То је Твоја воља и ми јој се морамо покоравати.

Када се један камен баци у воду он прави концетричне кругове који се шире. Тако и смрт Димитрија Љотића иде тугом његовој породици; његовој мајци Љубици тамо далеко у Смедереву, његовој супрузи Ивки ${ }^{10}$, његовом брату

\footnotetext{
${ }^{8}$ БК 250 Ова реченица је изостављена.

${ }^{9} \mathrm{CП} 109$ Текст почиње следећом реченицом: Ако је истинита она народна, „као гром из ведра неба“, онда се она обистинила, потврдила јутрос када смо добили вест о смрти Димитрија Љотића.

10 ЂВ 87 испуштено Ивки
} 
Јаши, његовим синовима и његовој кћери. Други круг иде кругу добровољаца, његовим сапутницима и једномишљеницима у миру и рату, у добру и злу, у радости и жалости. Трећи круг туге ${ }^{11}$ иде са $^{12}$ дичним четницима и са оним ${ }^{13}$ коме је већ четири године земља простирач а небо покривач ${ }^{14}$. И сад долази ${ }^{15}$ и четврти круг, који обавија цео свет, јер Љотић није био само наш, он је припадао човечанству, Европи, свету.

Димитрије Љотић био је државник, учитељ и хришћанин. Он није био само државник, он је био хришћански државник. За последњих $150^{16}$ година ми смо имали великих политичара, великих људи као што су Гарашанин, Јован Ристић и Никола Пашић, али ти су људи били велики за своје време, и у границама Србије, док је Димитрије Љотић зашао у велике кругове светске политике. То је био политичар са крстом. Имао сам прилике да га једном чујем у манастиру Жичи када је рекао: „Српски ${ }^{17}$ народ неће бити срећан, док сав ${ }^{18}$ свет не буде срећан.“ Он је био учитељ који је учио најпре делима па тек онда речима, упућивао је и сам је био пример. Никад није говорио а да делом није показао. Ништа није било да је говорио, а да није делом ${ }^{19}$ остварио. О да су такви били сви наши учитељи? Христос је рекао: „Треба радити па учити, а не само учити.“

О њему ће се говорити као човеку, државнику и дубоком хришћанину, и ту ${ }^{20}$ је он био највећи. Он почиње од себе, а то користи свету. Ако почињеш од периферије, од

\footnotetext{
11 БК 250 недостаје реч: туге СП 110 недостаје реч: туге

12 СП 110 ка

${ }^{13}$ БК 250 к оном СП 110 к ономе

14 ЂВ 87 прекривач

15 ЂВ 87 одлази

16 ЂВ 87 16о; БК 252 сто педесет; СП 110 сто педесет

17 ЂВ 88 Наш

18 ЂВ 88 цео

19 ЂВ 88 делом није

${ }^{20}$ БК 251 то СП 110 то НБ то
} 
другог, а не од себе онда не користиш никоме. То је било његово гесло. Димитрије Љотић је био човек дубоке вере. Он је као министар правде додавао кадионицу свештенику у цркви. Многи су се томе ругали, али он се није стидео. Он је говорио: „Ја идем да испитујем вољу Господњу, па кад је сазнам ићи ћу за њом, необазирући ${ }^{21}$ се ни на ${ }^{22}$ лево ни на ${ }^{23}$ десно.“ Без Димитрија Љотића осећа се велика празнина, а то је празнина која се не може лако попунити.

Дрво је отсечено, али Бог зна шта ради и ми се морамо покоравати његовој вољи. Ако је дрво отсечено, али из отсеченог дрвета никле су многе младице а то су многи и многи Љотићи. Ако је пао Димитрије Љотић, десетине хиљада српских јунака под оружјем заједнички сједињени, не појединци, него заједнички замениће 24 Димитрија Љотића. Димитрије Љотић је човек који је надахњивао људе. Носио је тешки крст и у рату и у миру, јер ни у миру му људи ${ }^{25}$ нису хтели дати мира. А у рату је извршио своју дужност и као војник и као грађанин. Баш они који су били на површини и који су били глава народна, нису га разумели. Зато смо и пропали што нисмо знали ценити такве вредности.

Бог га је узео баш у своје време. Рећиће неко: узели су нам га. Али га нису ${ }^{26}$ узели, јер је он дао упут својим животом и својим трудом до сада. Колика понизност, какав аскетизам, испосник Светогорски, какве молитве, дечје милине!

Ми благодаримо њему, његова Светост и ја и ${ }^{27}$ захваљујемо му се ${ }^{28}$ што смо дошли из заточења до Беча, и од Беч[а] овамо. Ми не можемо то никад заборавити највернијем сину Српства.

21 ЂВ 88 не обазирући се СП не обазирући се

22 БК 253 недостаје реч: на СП 111 недостаје реч: на

23 БК 253 недостаје реч: на СП 111 недостаје реч: на

24 БК 253 су заменици СП 111 су заменици

25 ЂВ 89 људи му

26 ЂВ 89 нису га

${ }^{27}$ БК 253 уместо везника „и“ стоји запета - ,

28 ЂВ 89 недостаје реч: се СП 11289 недостаје реч: се 
Када сам говорио са њим у Бечу о сједињењу наших народних националних снага, он је, говорећи о ономе за кога сам рекао да му је већ четири године земља простирач а небо покривач ${ }^{29}$, смерно одговорио $^{30}$ : „Он нека заповеда, ја ћу слушати. Он нека буде на врху, ја ћу на дну. Ја ћу му ноге прати.“ И дошло је до јединства ${ }^{31}$.

Ко је познавао тога човека, морао га је волети. Он је био идеолог светски, широке душе, лав у храбрости а јагње у кроткости. Говорио је : „Ако учинимо све народе срећним бићемо и ми срећни“. Чедо Милић, велики мостарски јунак, рекао је : „Још сам видео јунака, али јунака као Љотића нигде 32. “ О њему ће се зато писати књиге $^{33}$. Писаће не само Срби, него ${ }^{34}$ и сви Европљани који су га познавали.

Било је људи који су говорили да он воли да прима од некуд, да сакупља, да гомила. Али где су његове куће? Где му је имање? Где су му куле? Где су му поља? Ја тога не видим. Али ${ }^{35}$ је био велики богаташ духом, поштењем, вером. Духован човек, карактеран, поштен, одлучан и религиозан. Он је био толико богат душом, да је од ње могао дати и другом, позајмити осталим ${ }^{36}$, увек спреман да даде ${ }^{37}$ савета и лепу реч. За њега политика није била акробатика, него етика. Не акробатика, него етика! ${ }^{38}$ Он је био репрезентатор $^{39}$ душе и срца српскога ${ }^{40}$, чари и истине српске. Он је био идеолог хришћанског национализма.

\footnotetext{
29 ЂВ 89 прекривач

30 ЂВ 89 рекао

31 БК 253 И дошло је јединство СП 112 И дошло је јединство

32 ЂВ 89 нисам

33 ЂВ 89 недостаје реч: књиге

34 ЂB 9 о већ

35 ЂВ 90 Али зато

36 ЂВ 90 осталима БК 254 осталима СП 112 осталима

37 ЂВ 90 да

38 БК 253 нема целе реченице

39 ЂВ 90 репрезентат

40 ЂВ 90 српског
} 
Он је волео све ${ }^{41}$ војводе. Он је то мени причао, а исто о њему причале су ми ${ }^{42}$ војводе, и кружиле похвалнице ${ }^{43}$ о њему.

Један велики војвода, који је овде међу нама рекао ми је једном приликом ${ }^{44}$ пре кратког времена: „Не могу се од њега одвојити. Речи из његових уста теку као мед. Он је прави репрезентатор ${ }^{45}$ српске политике.“ Он је дао толико ${ }^{46}$ од себе, па да је живео још 5047 година он не би имао шта више да да. Он је дао одговора ${ }^{48}$ на сва питања. Он је у својој идеологији обухватио све гране народног живота.

Жалимо га сви, жали га свак, ${ }^{49}$ жале га и Немци. Многи су му пребацивали да се сувише наслања на Немце и то баш они који нису били народни људи, који поседују виле и богатства, и који као јазавци припремају себи унапред ${ }^{50}$ богатство за сто година. Али он је највише критиковао Немце, и баш зато су га они волели ${ }^{51}$ и поштовали. Критиковали су га само они који га нису познавали.

Колико је само волео своје војнике. Причао ми је један официр из његове пратње: „Када смо отступали из Београда, на путу смо застали и делили храну војницима који су били гладни. Када смо поделили храну пришао сам Љотићу и рекао му да је још остало хране само за мене и њега, нашто $^{52}$ ми је он рекао: „Подели и то. Ми ћемо лакше. Сад и тако ${ }^{53}$ идемо да спавамо, а лакше се спава кад се не једе.“ И

\footnotetext{
41 ЂВ 90 вас

42 БК 254 причале су ми и СП 113 причале су ми и

43 ЂВ 90 су похвале

44 ЂВ 90 недостају речи: једном приликом

45 ЂВ 90 репрезентат

46 ЂВ 90 толико дао

${ }^{47}$ БК 254 педесет СП 113 педесет

48 ЂВ 90 одговоре

${ }^{49}$ БК 254 . Жале га и Немци. СП 113 Жале га и Немци

50 ЂВ 90 недостаје: себи унапред

51 БК 256 и ठаш зато су га они поштовали

52 ЂВ 91 нашта БК 256 Нашта СП 113 Нашта

53 ЂВ 91 онако
} 
тако сам учинио." Он је поштовао човека изнад свега, само најприје ${ }^{54}$ изнад свега Бога.

Он је био велики човек. Оно што је посадио ухватило је дубока корена, и све што је урадио мирисаће.

Добровољци, певајте у славу Димитрија Љотића! Четници, плетите венце славе! Срби спомињајте се ${ }^{55}$ Димитрија Љотића!

Пала је највећа жртва. Боже не тражи више. Боже, доста, молимо Те, узео си много и као највећу жртву њега. Боже, нека буде доста.

Ја верујем да је ова велика ${ }^{56}$ жртва капија која ће нас досвести до слободе. Димитрије Љотић је капија наше слободе, то је капија наше нове Отаџбине ${ }^{57}$.

Зато сви браћо, помолимо ${ }^{58}$ се за душу великога ${ }^{59}$ човека $^{60}$ и нека га прими у царство своје. Нека нам Бог услиши молитве, а њему нека да место које заслужује.

Бог да прости души Димитрија Љотића. Во вјеки вјекова $^{61}$ амин. ${ }^{62}$

Није мртав Димитрије Љотић. Он сада припада читавом Српству63. Он сада припада небеској Србији. А мртви су јачи него живи. Он је сада јачи, него када је био жив и спутан. Он сада још више ради и поседује још више снаге. Он тек сада ради.

$$
\text { С Л А В А М У! }{ }^{64}
$$

\footnotetext{
54 ЂВ 91 најпре и БК 256 најпре и СП 114 најпре и

55 ЂВ 91 спомињите БК 256 спомињите се СП 115 спомињите се НБ спомињите се

56 ЂВ 91 оволика

57 ЂВ 91 отаџбине БК 256 Димитрије Љотић је капија наше нове Отаџбине СП 114 Димитрије Љотић је капија наше нове Отаџбине

${ }^{58}$ БК 256 молимо СП 114 молимо

${ }^{59}$ БК 256 великог

60 ЂВ 91 великом човеку

61 БК 256 . Амин. СП 114 . Амин

62 ЂВ 91 Во вјеки вјеков. Амин! НБ Во вјеки вјеков. Амин!

${ }^{63}$ СП 114 недостаје читава реченица

${ }^{64}$ БК 256 Хвала му. СП 114 Хвала му.
} 


\section{Када је настао говор и ко га је забележио?}

Епископ Николај, који је практично цео ток Другог светског рата био у немачкој интернацији, пребачен је заједно са Патријархом Гаврилом на територију Немачке средином септембра 1944. године. Иако непланирано, високи великодостојници Српске Православне Цркве интернирани су у концентрациони логор Дахау, из којег су пуштени тек крајем новембра или почетком децембра 1944. године (Ломпар 2018, 16-25). Димитрије Љотић је заједно са сопственим борцима напустио територију Србије пред наступајућим партизанским и совјетским јединицама. Пребацили су се у Словенију, где су се заједно са јединицама Мочила Ђујића и Добросава Јевђевића борили под командом Одила Глобочника (Janjetović 2016, 673-685). Димитрије Љотић погинуо је у аутомобилској несрећи на путу ка штабу Момчила Ђујића која се догодила се око 10 часова увече 23. априла 1945. године (Карапанџић 2012, 250). Војници Момчила Ђујића стигли су на место несреће и пренели повређене у болницу, док је тело Димитрија Љотића пренето у капелу у Светом Петру. ${ }^{65}$ Ту је 24. априла у 18 часова и 15 минута одржао говор епископ Николај Велимировић. ${ }^{66}$ Оно што се са сигурношћу може тврдити јесте да му је претходио одређени црквени обред. Међутим, око природе тог обреда, као и тога ко је чинодејствовао постоје извесна спорења. Сам Бошко Костић наводи да је „после помена епископ Николај одржао говор“, тиме именујући тај обред као помен, али не говорећи ко га је служио (Костић 1949, 250). У литератури се, међутим, усталило мишљење да је тада вршено опело. Карапанџић и Стефановић, иако се слажу по питању опела, не слажу око тога ко га је служио. Стефановић наводи

\footnotetext{
65 Фотографија Димитрија Љотића на одру објављена је у Карапанџић 2004, 62 .

66 Војни Архив (ВА), Недићева архива (НА), Ф3, Дз3, Говор епископа Николаја над одром министра Димитрија Љотића.
} 
да су и Патријарх Гаврило и Епископ Николај служили, док Карапанџић тврди да је служио „Епископ Николај уз асистенцију свештеника из Динарске четничке дивизије“ (Карапанџић 2012, 250; Стефановић 1984, 327). Карапанџићев исказ о Николају као служитељу поткрепљује и Душан Поповић, који међутим тврди да је заправо служен парастос (Поповић 2005). Велибор Џомић је према нашем мишљењу оправдано указивао на то да је служен помен, што је у складу са Костићевим писањем и текстом у Нашој $\delta о р \delta и .{ }^{67}$ Према сведочењима, Патријарх Гаврило није говорио након помена, а вероватно није ни чинодејствовао. На основу самог документа (који почиње са Ваша Светости), али и сведочења, може се тврдити да је он био присутан у капели. Оно око чега се извори слажу јесте да Николај Велимировић није читао говор са папира, већ да је говорио из главе. Самим тим не постоји аутограф говора који би представљао апсолутни доказ његове аутентичности. ${ }^{6}$

Истовремено, постојала су спорења око тога ко је овај говор записао. Према сведочењу Бошка Костића нико од збораша није био присутан у капели током говора, већ је он тај говор добио „од присутних свештеника и четника.... они су тај говор записали“ (Костић 1949, 258). Током полемике са Велибором Џомићем, Боривоје Карапанџић је као састављача текста именовао „проту Илију Булована“. Џомић је оспоравао ово тврдећи да прота Булован није био стенограф, и да самим тиме не би био у стању да цео говор

\footnotetext{
${ }^{67}$ Џомић је указивао на то да у СПЦ не постоји пракса служења опела дан пре сахране. С обзиром на то да је Димитрије Љотић сахрањен 25. априла 1945. г. он је доказивао да је Николај Велимировић вршио помен. Према писању Наше борбе том приликом је служен помен, који је почео у 17 часова, а тек је сутрадан, на сахрани, служено опело (којем нису присуствовали ни Патријарх ни Епископ Николај). Џомић 2009, 245; Наша бор $\delta$, 25. 4. 1945.

${ }^{68}$ Момчило Ђујић је тврдио да је током ноћи 23. априла Николај Велимировић „често долазио у канцеларију мог Штаба да нешто пише“, али је истакао да је он „одржао“, а не прочитао говор, што је у сагласју са осталим сведочењима. Цитирано према Пауновић 2006, 35-36.
} 
запише, сматрајући да један свештеник не би бележио говор док епископ говори (Карапанџић 2003; Џомић 2004). О томе да је тврђење Боривоја Карапанџића нетачно сведочи и Душан Поповић, који је, према сопственом исказу, као члан хора Динарске дивизије био присутан на помену. Према његовом сведочењу, чланови просветног одсека Динарске дивизије су, седећи за столом постављеним иза хора, са леве стране ковчега, записали говор који је потом откуцан и „дељен народу“ (Поповић 2005). Без намере да оспоримо аутентичност Поповићевог сведочења, чини се да је оно изазвано Џомићевом критиком Карапанџићевог писања. Стога је у релативно кратком Поповићевом чланку тако много пажње посвећено намери да се докаже тачност стенографа. Према њему, сви су „са напетошћу исчекивали Владикин говор“, те се просветни одсек „на време потрудио да се говор запише и сачува“. Они су били „увежбани у хватању радио вести“ и „сместа су отишли у канцеларију... записе сравнили, откуцали на машини умножили“ (Поповић 2005). Оваква верзија догађаја намеће неколико питања. Због чега би се са толиком напетошћу очекивао говор Николаја Велимировића, да би у капелу био унет сто и упошљени стенографи да га запишу? Такође, уколико је умножени говор „дељен народу“, како је могуће да нико сем двојице збораша (Бошка Костића и Ђура Врге) који нису били у том тренутку присутни, није сачувао и објавио тај документ?

\section{Оспоравање и одбрана аутентичности}

Када се расправља о аутентичности говора Николаја Велимировића на одру Димитрија Љотића мора се имати у виду да нико није оспорио да је Николај доиста говорио над његовим одром. Другим речима, споран је само текст који је атрибуиран Николају, а не сама чињеница да је он говорио. До сада није пронађен извор првог реда који би до краја 
разрешио ово питање, те су спорења и даље актуелна. Ми ћемо настојати да прикажемо до сада изнете аргументе обе стране али и да допринесемо сопственим истраживањем и интерпретацијама овој дебати.

Излагања обе стране у дебати се заснивају углавном на посредним доказима који су подложни интерпретацији. Одличан пример представља чињеница да је Николај Велимировић једанаест година надживео Димитрија Љотића, умревши 1956. године. Током тог времена он није нити ауторизовао нити демантовао свој говор над одром Димитрија Љотића. С обзиром на то да Николај Велимировић није никада ауторизовао овај говор, он се није нашао, за разлику од других говора, међу његовим Сабраним gелима. И једна и друга страна наводиле су овај податак да би оснажиле своју тврдњу. За једне је то био знак прећутног слагања са његовим садржајем, док су други то приписивали епископовој жељи да се не продубљују раздори међу националном емиграцијом. Епископ Николај Велимировић је на једној приватној вечери у емиграцији, наводно према сведочењу Милета Вујиновића, на питање да ли је он доиста изговорио те речи, одговорио „јако же рекох јесам“.69 Ово сведочење је објављено тек 1992. године, након смрти свих присутних људи, те се не може сматрати апсолутним одговором на питање аутентичности.

Због свог говора Епископ Николај је доиста трпео жестоке критике у емиграцији. Вељко Рашевић га је стога назвао „некада просвећеним владиком“ (Рашевић 1953, 7). Чланови савеза Ослобођење су захваљивали Бошку Костићу што је „у жељи да Владику Николаја употреби као једног живог сведока - срушио у српској емиграцији мит баш онога за којим су „браћа добровољци“ тако велику потребу имали!“70 Слободан Драшковић, је према Карапанџићу,

69 Аноним, „Сећање на Владику Николаја“, Хиланgар, бр. 38, 1992, 24-25.

70 У истом чланку изнета је жестока критика Николаја Велимировића. Анонимни аутор је написао да „Владика Николај има храбрости и образа да каже да је „Димитрије Љотић капија слободе нове Отаџбине“! Ту 
чак наговарао Епископа Николаја да се одрекне говора над Љотићевим одром (Карапанџић 2004, 53). Међутим, не би требало тврдити ни да Епископ Николај није чинио покушаје да се дистанцира од Димитрија Љотића. Замољен од збораша Ђура Врге 1949. године да приложи своје сећање на Љотића, које би било објављено у књизи сећања, Николај Велимировић му је одговорио: „На ваше питање о + Д. Љотићу могу Вам укратко рећи, да сам ја покојника високо ценио због његове велике побожности. У његове политичке идеје нисам никад улазио, нити ми је познат рад његових службеника за време рата, пошто нисам био на слободи“ (Врга 2007, 93). Из цитираног писма се јасно види настојање да се од Љотића удаљи. Такође, теза да никада није улазио у његове политичке идеје је у очигледном несагласју са раније изреченом тврдњом да је „он (Димитрије Љотић, Р. Л.) ... у својој идеологији обухватио све гране народног живота“"71

Овакво удаљавање од Димитрија Љотића није значило раскид везе са његовим истомишљеницима. Алекса Тодоровић, најпознатији зборашки свештеник, остао је близак сарадник Епископа Николаја, и био је уредник његове библиотеке Свечаник (Карапанџић 2003). Он је и раније, пре рата, сарађивао са Николајем Велимировићем као свештеник Жичке епархије. Учествовао је и у објављивању Сабраних gела Николаја Велимировића у којима, међутим, говор није објављен (Џомић 2009, 244).

Додатно индикативно за расправу о односу Николаја Велимировића према Димитрију Љотићу у емиграцији јесте његово писмо игуману Хиландара архимандриту Никанору од 10. марта 1956. У писму које је приватне природе Епископ Николај се интересује за стање у манастиру, нова

ће „капију слободе“ да сачува стари владика за себе и Марисава Петровића, а српски народ ће ићи својим путем...“ Аноним, „Глуво доба“, Наша реч, 1. 9. 1949.

${ }^{71}$ Војни Архив (ВА), Недићева архива (НА), Ф3, Д33, Говор епископа Николаја над одром министра Димитрија Љотића. 
чуда итд. У завршетку писма је написано: „Спомени на литургији моје родитеље $†$ Драгомира и монахињу $†$ Катарину. Спомени и 3 велика срп(ска) мученика Димитрија, Дражу и Милана.“ (Џомић 2009, 384). Овакво изједначавање Драгољуба Михаиловића, Милана Недића и Димитрија Љотића у складу је са његовим каснијим освртом на Други светски рат: „Од првог рата на овамо у крилу српског народа извиле су се три велике личности: између ратова Димитрије Љотић као реакција против социјалне структуре. У почетку и уједино завршетку двонедељног рата Дража Михаиловић, као продужетак двадесетседмог марта. А за време окупације Милан Недић, као ватрогасац, спаситељ и ублажитељ невоља, тегоба и страдања“"72

Чини се да је однос Николаја Велимировића према Димитрију Љотићу у промењеним околностима послератног света био амбивалентан. Са једне стране није се желео од њега у потпуности дистанцирати, али са друге није желео ни да учествује у изградњи култа личности и готовој апотеози Димитрија Љотића коју су у емиграцији спроводили збораши. Управо на тај начин односио се и према свом наводном говору над Љотићевим одром, те га није ни порекао ни потврдио. Стога сматрамо да понашање Николаја Велимировића у емиграцији не може да се сматра дефинитивним одговором на питање аутентичности.

Са друге стране, у дебати о аутентичности изостало је истраживање докумената Српског добровољачког корпуса и размишљање о томе да ли она могу бити путоказ. С обзиром на то да је Димитрије Љотић био spiritus movens Збора и Српског добровољачког корпуса, вођство СДК морало је да упозна трупе са губитком „Вође“ и „Учитеља“. Две такве наредбе од 25. и 26. априла 1945. које обавештавају о Љотићевој смрти не спомињу говор Николаја Велимировића над његовим одром. Посебно важан документ је Десейослов наше йобеgе од 26. априла. У њему четрнае-

72 Аноним, „Сећање на Владику Николаја“, Хиланgар, бр. 38, 1992, 24-25. 
сторица виђенијих збораша, међу којима и Бошко Костић, дају десет разлога зашто борци СДК не смеју да падну у очајање због смрти Димитрија Љотића. Документ је веома исцрпан и панегирично обојен према Љотићу. Они добровољцима поручују следеће: „Знај да у овом и сваком другом часу корача са тобом плејада јуначких синова нације са Бесмртником на челу“. ${ }^{73}$ Ни у овом документу се не помињу ласкаве речи које је упутио Николај Велимировић, што је посебно индикативно ако се узме у обзир да је, према сопственом исказу, Бошко Костић имао у рукама говор Николаја Велимировића већ 24. априла увече. Са правом се може поставити питање због чега су одлучили да се не позову на говор Епископа Николаја који је уживао огроман углед међу њиховим борцима. Такође, ни главне словеначке новине Jyйро и Словенеи, које су тог дана пренеле вест о Љотићевој погибији не спомињу да је Николај Велимировић одржао говор над његовим одром. ${ }^{74}$

Истовремено може се поставити питање због чега се сачуване верзије у тој мери разликују. Разлике јесу бројне али нису суштинске (замениће или су заменици, Слава му или Хвала му, вас војводе или све војводе итд...). Ниједна од њих не мења природу изговореног текста. Разлике у интерпункцијским знаковима и уређењу параграфа могу се занемарити, јер, како смо раније показали, аутограф говора вероватно не постоји, те је читава организација говора неаутентична. Међутим, постојеће разлике ми сматрамо важним. Њихова учесталост и разноликост елиминише могућност да су и Костићев и Вргин текст настали на основу документа који се чува у Војном Архиву, јер сматрамо невероватним да би оба аутора у толикој мери грешила приликом прекуцавања. Такође, Бошко Костић је објављивао факсимиле оних докумената које је поседовао, попут

\footnotetext{
${ }^{73}$ ИаБ, Збирка о раду Љотићеве организације 3бор (1929), кутија 2, Десетослов наше победе.

${ }^{74}$ Anonim, „Dimitrij Ljotić se je smrtno ponesrečil“, Jutro 26. 04. 1945; Anonim, „Dimitrije Ljotić smrtno ponesrečil“, Slovenec 26. 4. 1945.
} 
Љотићевих писама Драгољубу Михаиловићу, што овде није случај. Решење ове дилеме могло би лежати у чињеници да је, према Поповићевом исказу, више људи записивало говор. Иако је он тврдио да су стенографи „сравнили“ верзије, могуће је да су постојеће разлике резултат рада неколико стенографа.

\section{Ауторизована дела Николаја Велимировића}

\section{— могућности компарације?}

С обзиром на то да по свим сведочењима аутограф никада није постојао, о аутентичности овог говора може се расправљати и уколико се у обзир узму друга дела Николаја Велимировића око којих не постоји спорење. Већ спомињана песма у десетерцу о националној слози је веома важна. Она је такође објављена у књизи Бошка Костића, али за разлику од говора, она није изазвала контроверзу и прихваћена је као аутентична (Костић 2011, 235-236; Димитријевић 2007, 95-96).

Оно што се према нашем мишљењу може сматрати аргументом у корист тезе о аутентичности говора јесте чињеница да се у њему на два места чине јасне алузије на Драгољуба Михаиловића. Он се у тексту назива „онај коме је већ четири године земља простирач а небо покривач“. Сматрамо да се са великим степеном сигурности може тврдити да је у питању Драгољуб Михајловић. У случају да је говор над одром у целини неаутентичан, не сматрамо вероватним да би љотићевски фалсификатор посветио тако много простора генералу Михајловићу са којим односи током окупације ипак нису били тако добри као 1945. године. Заправо, добровољцима је било лакше да се збратиме са западним деловима Југословенске војске у отаџбини, са који- 
ма током рата практично нису имали никаквог додира. ${ }^{75}$ Такође, ако упоредимо ову алузију на Драгољуба Михаиловића са оном изреченом у већ цитираној песми увиђамо велике подударности. Оба пута он остаје неименован (Знај му име, али іа не кажи) и оба пута је истакнуто његово четворогодишње жртвовање (четиири іоgине земља иростичрач а небо йокривач и Шйо наg Срйсиввом четиир' тьей стиражи). Такође, у оба дела позивано је и слављено јединство националних снага у Словенији.

Истовремено, веома интригантно јесте појављивање две речи у говору у ијекавској варијанти српског језика. У питању су речи „нашто“ и „најприје“. Оне се у ијекавској варијанти појављују само у документу из Војног Архива и

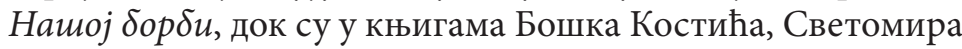
Пауновића и Ђура Врге обе речи екавизиране у „нашта“ и „најпре“. С обзиром на то да је Епископ Николај углавном писао екавском варијантом српског језика може се поставити питање порекла ове две речи. Постоје, према нашем мишљењу, две могућности. Прва да је Епископ Николај сам употребио ијекавски облик, а друга да је то контаминација стенографа. У случају да је доиста Николај тако изговорио поставља се питање мотивације. У песми се такође неколико речи налази у ијекавској варијанти (Бјеху, љета, свијет, пјевачкијех). Од споменуте четири речи, ијекавска варијанта две речи (свијет, пјевачкијех) се јасно може објаснити чињеницом да је песма у десетерцу, те да ијекавска варијанта речи повећава број слогова. Међутим, с обзиром на то да је исти број слогова и у речи лето и љето, као и беше и бјеше, за употребу ијекавице у ове две варијанте могу постојати само стилистички разлози. Овакво тумачење говори у прилог аутентичности говора. Алтернативно тумачење, којем смо ми склонији, јесте да је у питању контаминација стенографа, који је као припадник Динарс-

\footnotetext{
75 Поједини збораши су били у оквиру Ђујићевих јединица. Опширније о акцијама збораша ван Србије у Војіс́ 1996, 253-264.
} 
ке дивизије, у брзини написао реч на сопственом, источнохерцеговачком дијалекту српског језика.

У ауторизованим Велимировићевим делима се, такође, могу наћи мисли изречене у овом говору. У намери да охрабри Драгољуба Михаиловића и његове борце, он им је упутио писмо у фебруару 1945. године у којем је написао: „Нека Вам је Небеска Србија на помоћи. Јачи су мртви од живих. У Бога нема мртвих“ (Џомић 2003, 434). Готово иста конструкција налази се у говору над одром: „Он сада припада небеској Србији. А мртви су јачи него живи“ ${ }^{\text {“76 } \mathrm{Ca}}$ друге стране говор који је Епископ Николај одржао на парастосу генералу Михаиловићу 1954. године, прилично је умеренији, и фокус је на националном јединству. ${ }^{77}$ Такође, уколико посматрамо некрологе Николаја Велимировића објављене у његовим Сабраним gелима, можемо уочити да је често навођење примера, и исказа других личности (у говору Чеда Милића, једног војводе), Николај Велимировић користо у свом писању (Велимировић 2001, 809-890).

\section{Закључак}

У целини посматрано, питање аутентичности говора Николаја Велимировића је превасходно политичко питање, подстакнуто јасним разлозима његове канонизације. Прво оспоравање које је покренуо Атанасије Јевтић било је много обазривије од његовог другог „таласа“ и текстова Велибора Џомића и Милослава Самарџића (Самарџић 2004). Аргументи оспораватеља нам се не чине довољно убедљивим да би се говор могао одбацити као „љотићевски фалсификат“. Међутим, ми не желимо ни да тврдимо да је говор „од речи до речи“, како је то писао Момчило Ђујић, аутентичан. Међу исказима сведока постоји низ несугласи-

\footnotetext{
76 ВА, НА, Ф3, Дз3, Говор епископа Николаја над одром министра Димитрија Љотића.

77 Текст говора објављен је у Кнежевић 2017, 665-667.
} 
ца, непоклапања и различитих верзија. Практично све што jе о говору написано било је пуно одступања. Као што смо приказали, постоје различите (понекад супротне) верзије његовог текста, али и чињеница као што су: ко га је записао или ко је служио црквени обред. Додуше, расправа је вођена тек четрдесет година по његовом изговарању и њу су водили, или људи који тада нису били присутни, или они који су били у дубокој старости. Чињеница да је говор записивало неколико стенографа могла би објаснити разлике у његовом тексту.

Коначан одговор на питање аутентичности овог говора веома је тешко дати, јер по свим исказима аутограф није постојао. Ми предлажемо хипотезу о његовој делимичној аутентичности. И сам Атанасије Јевтић је признавао да „ако ту и има Николајевих мисли и исказа, то је ствар само његових политичких ставова и опредељења или идејних слабости, то јест оне врсте грешака без којих има ли човека у историји рода људскога?“ (Јевтић 1986в, 56; Јевтић 2006). Са друге стране, Магазиновић је обазриво примећивао да је могуће да цео текст говора није аутентичан. «Николај је текст говора признао као свој. Рекао је да постоје неки мали недостаци, али да у суштини текст одговара ономе што је он рекао» (Magazinović 2010, 235). Сматрамо да се за његове поједине делове може тврдити са великим степеном вероватноће да су у питању речи Николаја Велимировића. Такође, уколико не постоје спорења око песме Николаја Велимировића о националној слози, а с обзиром на јасне сличности ова два текста, она може бити додатан аргумент о аутентичности говора. Поједини искази, попут оног да је Љотић „у својој идеологији обухватио све гране народног живота“, у супротности су са касније изреченим мислима Николаја Велимировића. Велибор Џомић је оправдано указивао на манипулацију говором Митрополита Јосифа у Новом Времену 1943. године, као доказу да су колаборационисти и раније дописивали и мењали реченице које су им биле битне (Џомић 2009, 90-91). У цели- 
ни посматрано, наше је мишљење да се говор не може одбацити као фалсификат, али да је потребна извесна доза скепсе према томе да ли је он доиста одговара „од речи до речи“ мислима изреченим над Љотићевим одром 24. априла 1945. године.

\section{$* * *$}

\section{Списак извора и литературе}

\section{Необјављени извори:}

Војни Архив (ВА), Недићева архива (НА)

Историјски архив Београда (ИАБ), Збирка о раду Љотићеве организације 3бор (1929)

\section{Објављени извори:}

Anonim. 1945. „Dimitrij Ljotić se je smrtno ponesrečil“. Jutro, 26. 4. 1945.

Anonim. 1945. „Dimitrije Ljotić smrtno ponesrečil“. Slovenec, 26. 4. 1945.

Аноним. 1945. „Певајте у славу Димитрија Љотића“, Наша Борба, 25. 4. 1945.

Аноним. 1992. „Глуво доба“. Нама реч, 1. 9. 1949.

Аноним. 1992. „Сећање на Владику Николаја“. Хиланgар, бр. 38, $1992,24-25$.

Ђујић, Момчило. 1987. „И ја сам сведок“. Србија: іллас срйских бораиа, април 1987.

\section{Литература:}

Bojić, Mirko. 1996. Jugoslavenski narodni pokret Zbor. Beograd: Narodna knjiga. 
Byford, Jovan. 2004. From „Traitor“"to „Saint": Bishop Nikolaj Velimirović in Serbian Public Memory. Jerusalem: SICSA.

Đorđević, Mirko. 2010. Kišobran patrijarha Pavla. Beograd: Peščanik. Janjetović, Zoran. 2016. „Pokret Zbor u poslednjoj fazi Drugoga svjetskog rata“. Časopis za suvremenu povijest, Vol. 48 (3): 673-685.

Magazinović, Hrvoje. 2010. Kroz jedno mučno stoljeće. Valjevo: Društvo Hilandar.

Велимировић, Николај. 2001. Сабрана gела, том 2. Линц: Православна црквена општина Линц.

Врга, Ђуро. 2007. Остиала су свеgочења. Београд: Рашка школа.

Глигоријевић, Мило. 2009. Емиірантии. Београд: Службени гласник.

Димитријевић, Владимир. 2007. Оклеветиани светиаи. Горњи Милановац: Лио.

Ђорђевић, Мирко. 2008. „Оклеветани антифашизам“. Данас, 22. о7. 2008.

Јевтић, Анастасије. 1986а. „Владика Николај и отац Јустин — о изграђивању Цркве“. Боїословље: орїан Православної боїословской факулиетета у Беоїраgу, година 30 (44) (1-2): 131-143.

Јевтић, Атанасије. 1986б. „Поводом напада на Владику Николаја“. Правоставље:: новине Срйске Пайријариије, година 2о, бр. 467 (1. септембар 1986): 11-12.

Јевтић, Атанасије. 1986в. „Поговор“. У Протосинђел Артемије

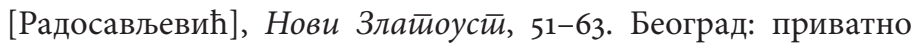
издање.

Јевтић, Атанасије. 2006. „Четири круга напада на Светог Николаја Српског“. Двери срйске, бр. 32, 2006.

Карапанџић, Боривоје. 20о3. „Одговор јереју Велибору Џомићу“. Кюижевне новине, 1-31. 12. 2003.

Карапанџић, Боривоје. 20о4. Виђеюа и разіовори са Светиим Николајем Жичким. Кливленд: Књижевни весник.

Карапанџић, Боривоје. 20о8. Зайиси са северо-америчкої језера Ири. Кливленд - Ваљево: Александар Павловић.

Карапанџић, Боривоје. 2012. Грађански рай у Србији 1941-1945. 4. издање [тј. 2. издање у издању Друштва Хиландар]. Ваљево: Друштво Хиландар. 
Кнежевић, Радоје, прир. 2017. Књиіа о Дражи. Београд: Catena mundi.

Костић, Бошко. 2011. За истиорију наших gана. Београд: Нова искра.

Ломпар, Растко. 2018. „Заточеништво Патријарха Гаврила и Епископа Николаја Велимировића у Дахауу 1944. године“. С̄̄uguje истиорије Иларион, бр. 3, 9-29.

Пауновић, Светомир. 2003. „Клевете и неистине Велибора Џомића“. Искра, 1. јун 2003.

Пауновић, Светомир. 2006. Светии Влаgика Николај срӣски и юеі̄ови йоштиоваоии и обожаваоии. Београд: приватно издање.

Поповић, Душан. 2005. „И ја сам сведок“. Искра, 1. 6. 2005.

Рашевић, Вељко. 1953. Оїлеg о схватианима Димитирија Љотиића. Париз: Наша реч.

Самарџић, Милослав. 2004. „До краја уз Хитлера“. Поїлеgи, јун 2004.

Стефановић, Младен. 1984. Збор Димийрија Љойића. Београд: Народна књига.

Џомић, Велибор. 2003. „Прилози за биографију Св. Владике Николаја у Другом светском рату“. У Свети Влаgика Охрияски и

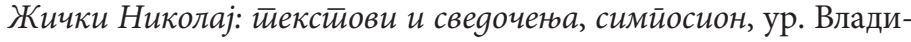
ка Атанасије Јевтић, 426-439. Жича - Краљево: Манастирска епархија Жичка.

Џомић, Велибор. 2004. „Код Срба нема индулгенција“. Книжевне новине, 1-30. 6. 2004.

Џомић, Велибор. 2009. Србска Црква, Љотиић и лооиићевии. Београд - Подгорица: Штампар Макарије - Октоих. 